\author{
SUMMARY \\ MEASUREMENT OF THE "SELECTION EFFORT " IN A PIG HERD \\ I. -- METHOD OF MEASUREMENT \\ II. - FIRST RESUITS
}

The annual genetic improvement may be expressed in terms of two components :

$$
\mathrm{G}=\mathrm{E}_{p} . \mathrm{E}_{\boldsymbol{s}} .
$$

I. $E_{q}$ depends on the trait involved, on the testing method used and on the practical conditions of its application. Also $E_{p}$ is partly a fonction of the own genetic parameters of the breed or herds selected.

2. $\mathrm{E}_{s}$ or " selection effort " is the ratio of intensity of selection to generation interval. This quantity, depending on the choice of parents and the duration of their utilization, measures the breeder's decisions of selection.

Practically, the selection pressure may be simply measured from the age and the performances of each parent, present in the herd on a fixed date. Also, a more precise measurement may be made by considering litter born on a given period (at least six months) and by weighting the results of each parent according to the number of its litters. Two programs based on these two methods of measurement were organized by " l'Institut technique du Porc " and the results could be estimated in 94 herds.

The selection effort observed in these herds varies between 22.3 points and -2.7 points per year (respectively I.I and - o.I standard deviation unit per year) but in most of the herds, it is estimated on about 4 points, which is very low.

These poor results are to be imputed to either to a breeders' misunderstanding of modern breeding methods, or to a too recent start of the selection programs.

\title{
NOTE SUR LE PROTOCOLE DE COMPARAISON de LIGNées MALES SPÉCialisées CHEZ LE PORG
}

\author{
P. SELLIER \\ Station de Génétique quantitative et appliquée, \\ Centre national de Recherches zootechniques, I. N. R. A., \\ 78350 Jouy en Josas
}

\section{RÉSUMÉ}

Le mérite comparé de lignées mâles spécialisées est à évaluer par la performance des produits de croisement d'un échantillon de verrats de ces lignées. L'objet de cette étude est de déterminer l'effectif $\mathrm{N}$ de verrats à contrôler sur un nombre donné de descendants pour avoir une probabilité 
égale à 80 ou 95 p. Ioo de détecter une différence donnée, au seuil de 5 p. roo. Les valeurs de N, calculées dans plusieurs situations, sont présentées sous forme graphique, ainsi que les variations de la capacité de contrôle requise en fonction de l'effectif de descendants mesurés par verrat. Il apparaît que, pour une égale efficacité du dispositif expérimental, cette capacité est plus faible si l'on adopte un schéma de testage minimum pour chaque verrat et si l'on recourt, quand cela est possible, à la méthode des couples (verrats apparentés).

\title{
SUMMARY
}

\section{A NOTE ON PLANNING THE COMPARISON OF SPECIALIZED SIRE LINES IN SWINE}

The compared merit of specialized sire lines should be judged on the performance of the crossbred progeny of a sample of boars of these lines. The purpose of this study is to find the minimum number $\mathrm{N}$ of boars to be tested on a given progeny group size to tave a probability of 0.8 or 0.95 to detect a specified difference at the 0.05 significance level. The values of $\mathrm{N}$, computed in several situations, and the variations of required testing ability in terms of boar progeny group size are presented graphically. It appears that, for equal experimental design efficiency, this ability is reduced by testing a smaller number of progeny per boar and by applying, when possible, the method of paired samples (related boars).

\section{ÉVALUATION ZOOTECHNIQUE DU PORG « BLANC DE L'OUEST 》}

\author{
P. SELLIER, C. LEGAULT, B. JACQUET et L. OLLIVIER \\ Station de Génétique quantitative et appliquée, \\ Centre national de Recherches zootechniques, I. N.R. A., \\ 78350 Jouy en Josas
}

\section{RÉSUMÉ}

Le Porc blanc de l'Ouest est la seule race locale française qui soit encore notablement utilisée aujourd'hui, surtout en croisement.

Les performances d'élevage des truies inscrites au Livre généalogique $(8,4$ porcelets nés vivants par portée) et les résultats des croisements simples et en retour avec la race Vevedeltes Landschweine indiquent clairement que le Porc Blanc de l'Ouest n'a pas un niveau de prolificité suffisant pour que son utilisation comme composante d'une truie croisée soit envisagée.

Dans une expérience de croisement entre les races Large White (LW), Blanc de l'Ouest (PBO) et de Piétrain $(\mathrm{P})$, les moyennes des types $\mathrm{P} \times \mathrm{LW}$, $\mathrm{PBO} \times \mathrm{LW}$ et $\mathrm{PBO} \times \mathrm{P}$ (race du père en premier) ont été respectivement : $5^{8} 5,634$ et $60_{4} \mathrm{~g}$ pour le gain moyen quotidien ; $3,78,3,72$ et 3,47 pour l'indice de consommation ; $2 \mathrm{r}, 8,22, \mathrm{I}$ et $\mathrm{I} 9,5 \mathrm{~mm}$ pour l'épaisseur de lard dorsal à $79,5 \mathrm{~kg} ; 52,6,49,9$ et $53 \mathrm{p}$. Ioo pour le rendement en morceaux nobles ; 917, 952, et $937 \mathrm{~mm}$ pour la longueur de carcasse ; $5,98,5,87$ et 5,81 pour le $\mathrm{pH}$ moyen de 5 muscles mesuré 24 heures post mortem ; 59,2, 55,5 et 57,4 P. Ioo pour le rendement global de la transformation en jambon 